\title{
Learning Local Wisdom through the Symbols of Ma'nene' Rituals in North Toraja: A Semiotic Perspective
}

\author{
M. Dalyan Tahir, Hunaeni Hunaeni, \& Sylver Tri Poetra \\ Universitas Hasanuddin, Makassar. Indonesia \\ dalyan1964@gmail.com
}

\begin{abstract}
ARTICLE HISTORY
Received : 2020-10-19

Revised : 2020-11-20

Accepted : 2020-11-27
\end{abstract}

\section{KEYWORDS}

Ma'nene' Ritual

Baruppu community

Meaning of symbols

Local wisdom

\begin{abstract}
The values of local communities are almost always highlighted in terms of tourism that little is known of how local wisdom can contribute to the generation. This study examines the meaning of symbols and interpretations of local wisdom in ma'nene' rituals in the Baruppu community of North Toraja Regency using a qualitative descriptive approach. Data on words and behavior in rituals were obtained through interviews, notes, records, visual and audiovisual documentation, and analyzed with Pierce's semiotic theory. The results of this study indicate that the implementation of the ma'nene' ritual is divided into two stages, namely: 1) Preparation (a) Ma'kongan ada', (b) Kapenomban pa'paranduk, (c) Manta'da, (d) Ma' pakande ada', (e) Umpasun bombongan; and 2) Implementation of (a) Ma'bungka', (b) Ma'kassa'i, (c) Massomba tedong, (d) Manglokko tedong sola bai, (e) Ma'pakande nene', (f) Mantutu', (g) Capenomban pa'paupu'. In carrying out the ritual, there are various symbols, including: (1) Tau-tau, (2) Bombongan, (3) Pangngan, (4) Kain ba'ru, (5) Tedong sola bai, (6) Bo'bo 'sola duku', (7) Punti leaves, (8) Tallang. Based on the semiotic analysis of the symbols in the ritual, several types of local wisdom were found, namely: (a) religious values, (b) brotherhood, and (c) unity.
\end{abstract}

\section{Introduction}

In the emerging Asian market, local communities' cultural practices are often brought up in discourse as opportunities to promote tourism and preserve heritage. This study is interested to mine the values of local wisdom to record them in academic literature and display how much local wisdom offer for education and that it is more than a "unique" element of a tourist destination (Alam \& Al-Muthmainnah, 2020; Dewi, Poedjiastoeti, \& Prahani, 2017). Specifically, this study focuses on the religious system, which is a guardian of emotions in local cultures, because it is intricately linked with three elements, namely (1) the belief system, (2) the religious ceremony system, (3) the people who adhere to that religion (Koenjaraningrat, 1992, p. 14). The government of Indonesia has designated Toraja, South Sulawesi, as a priority strategic tourism area (Kausar \& Gunawan, 2018), and the religious systems and models of inheritance of the Toraja people is the interest of this study.

The majority of the Toraja people adheres to Christianity, which was brought and spread by the Zending from the Netherlands (Panuntun et al., 2019). Long before, people adhered to animist beliefs that influence their traditions to this day, and the Toraja people still carry out distinctive burial procedures in rock caves which are often found on cliff ridges, scattered throughout the Toraja region. On the porch of each rock cave grave location, you can see rows of human statues (tau-tau) made of jackfruit wood. Inside were mortar-shaped coffins containing corpses, and human skulls scattered outside and inside the cave. The method of burial is closely related to the concept of life of the Toraja people, which states that their sacred ancestors came from heaven and came down to earth. Therefore, the bodies of people who have died should not be buried in the ground. For them it will destroy the sanctity of the earth which results in soil fertility.

The death according to the belief of Aluk Todolo (to $=$ people, dolo $=$ ancestor $)$ or Alukta culminates in the attainment of the greatest life in eternity in Puya (the world of spirits) as to buy puang (Pantheon/subordinate God). Therefore, funerals for the Toraja people become the most sacred moment in the journey of human life on earth. Aluk Todolo's belief illustrates that humans come from the sky, come down to earth, life, and will return to the sky after going through transformation.

The Toraja people uphold the doctrine that human life is to die, to the realm of eternity. In order to achieve peace in Puya, each corpse must perform selfcleansing as atonements for sins. For this reason, 
every corpse to be buried should be provided as much as possible according to the family's ability. The provisions in question are the spirits of a number of animals that will be sacrificed when the funeral ritual is carried out. The spirits of a number of sacrificed animals are expected and believed to be vehicles capable of taking the spirits of the dead to Puya.

The greater the number of animals sacrificed, the more perfect the journey to immortality will be. Besides, on the socio-cultural side, the higher the degree of the dead, the more animals are sacrificed. That is why burial or death rituals in the Toraja tribe can cost hundreds, to billions of rupiah which are generally held for 5-6 days, even up to a full month (Niswaty, Nur, \& Sesa, 2020). For those who have not been able to have their relatives buried, they will be mummified for a while at home, until the time when their immediate family is able to raise money and agree to hold a death ritual according to custom, namely, the Rambu Solo ceremony (Hasmawati et al., 2020).

Burial rituals also function as family reunions and refreshing kinship relations (Kobong, 1992, p.45). This opportunity is used to sit down to ask about their origins and tell stories because the Toraja people have rich folktales known as ulelean pare or puama which has significant roles for Torajanese in identifying their ancestors, knowing and understanding their cultures and histories, learning past lessons, and entertaining (Surya et al., 2017), means of sharing inheritance, proving the dignity of the Toraja people, alliance (gotong royong), means of artistic expression, and recreation through the momentum of the Rambu Solo ritual. These two contradictory but complementary functions give birth to the perception of the "party of death".

There are also songs at the ritual, which is the song of the guard at the funeral called Dondi. Dondi is sung sitting down all night, according to the tastes of the participants (Rappoport, 2009a: 33). In this ritual, singing plays an important role. Funeral rituals in Toraja are grueling activities with funds that leave most families in debt. These activities include: 1) Sending invitations to relatives and surrounding villages, and 2) The order of the rituals; a) dressing the bodies, b) the arrival of guests carrying pigs and buffalo, c) singing lamentations in a circular dance, during animal sacrifices, d) distributing meat, and e) burials (Rappoport, 2009b: 55).

The ma'nene' ritual is a complement to various Aluk Todolo rituals and is part of the Aluk Rambu Solo ceremony. ma'nene' ritual can be found especially in the Baruppu area, North Toraja Regency. The people in that area are still preserving their ancestral customs and traditions, and still deeply feel that individuals who have died remain an inseparable part of their living relatives. That is why in that area, some families are very concerned about the bodies of their relatives. This concern is shown by cleaning his grave at least once a year.

Ma'nene' rituals are held in the cemetery area by cleaning grave burrows, making offerings to ancestral spirits, changing new clothes for the corpse when the wrappers are old, and changing rotten tau-tau clothes. This ma'nene' ritual is carried out after the harvest as a tribute to the ancestors, but its main purpose is as a sign of gratitude to God.

The origins of this ma'nene' ritual came from a hunter named Pong Rumasek who found a corpse in poor condition in the mountainous forest of Balla. The body was then treated and buried in a safe place. Since Pong Rumasek has always received blessings on his farm and hunting. Pong Rumasek concluded that the bodies of people who have died must still be cared for and respected, even though the bodies are no longer in shape. Until now, the mandate of Pong Rumasek has been maintained in the form of its mutation as a means of performing the ma'nene' ritual, which if it is not done after harvesting, their farm will suffer damage (Interview with Beatrix Bulo', 80 years old, 27-09-2017, 15:00).

The Ma'nene' ritual is a complement to the Aluk Rambu Solo which is carried out after the funeral and after the harvest. ma'nene' rituals are sacred and must be performed. For the people of Baruppu and most of the Toraja people in general, they consider that this ritual is a form of representation of purification and respect for the spirits that will go to Puya. Even though many Toraja people have embraced heavenly religions, the customs and traditions of their ancestors are not easily abandoned.

For the people of Baruppu, the ma'nene' ritual is an annual mass ritual that is followed by all Baruppu families both living in the village and outside the region. ma'nene' is a tribute to all the spirits whose bodies were "buried" in stone graves in Baruppu. In Baruppu, the body should not be kept for more than five nights to wait for distant relatives. That is the unique habit of similar rituals in the Toraja cultural area. Thus, this event will truly become a reunion for the nomads.

Language as a means of communication for the people of Baruppu, generally grows in an oral tradition. Other forms of communication tools are symbolic. The Baruppu people use these symbols as part of a means of connecting humans with nature as well as supernatural beings and local wisdom, in interpreting life according to society.

Current developments show that the symbols in these rituals are now only understood by a handful of individuals who are mostly elderly (Akhrani \& Eka, 
2019). Meanwhile, most of the communities have shifted the ritual implementation according to their abilities and new beliefs. Such conditions are certainly very worrying about the cultural links of a society. Moreover, the Toraja people do not so far have a written tradition. Even though they consistently write down the concepts of the mind into unique and artistic symbols.

This research examines the cultural meaning of symbols in the ma'nene' ritual which is packaged in the formulation of the problem as follows: 1) How is the ma'nene' ritual phasing? 2) What is the meaning of the symbols in the ma'nene' ritual?, and 3) How is the interpretation of local wisdom implied in the ma'nene' ritual?

The objectives of this review paper are formulated to 1) describe the ma'nene' ritual stages, 2) reveal the meaning of symbols in the ma'nene' ritual, 3) understand the local wisdom interpretation implied in the ma'nene' ritual.

This study is expected to be useful, both theoretically and practically, namely: (1) Expressing symbolic meanings and cultural aspects contained in the ma'nene' ritual in the Toraja people of Baruppu through semiotic analysis tools; (2) Providing meaningful contributions to scientific development, especially regarding Toraja culture related to ma'nene rituals; (3) Completing the previously written documentation about Toraja culture; (4) Teaching materials about Toraja culture for students and young people in general; (5) Increase the attractiveness of tourist destinations in Toraja.

\section{Literature Review}

\subsection{Semiotic Theory}

Semiotics is used to explain the practice of interpreting signs. Semiotics, of course, sees how culture becomes the basis for thinking about the formation of meaning in a sign. Semiotics studies systems, rules, conventions that allow these signs to have meaning (Kriyantono, 2007; Potts, 2017). Because there is a tendency to view various social discourses as linguistic phenomena (Hamuddin et al., 2019; Piliang, 1998; Tanasy, Nasir, \& Yulianti, 2020), this study finds it possible to explore semiotics as a method to study into various scientific branches. The theory of semiotics is important to use in this study because this theory can help the writer study and analyze various data in the research field, especially the meaning of symbols contained in the ma'nene' ritual in the Barappu community of North Toraja Regency.

Peirce put forward the triangle meaning theory which consists of three main elements, namely the sign, object, and interpretant. A sign is something that has a physical form that can be grasped by the human senses and is something that refers (represents) other things outside the sign itself.

The sign according to Peirce consists of a Symbol (a sign that emerges from a deal), an Icon (a sign that emerges from a physical representation) and an Index (a sign that arises from a cause-effect relationship). Meanwhile, the reference to this sign is called an object. The object or sign reference is the social context that is the reference of the sign or something that the sign refers to. Interpretant or sign user is the concept of thinking of people who use a sign and lower it to a certain meaning or meaning that is in someone's mind about the object that a sign refers to. The most important thing in the process of semiosis is how meaning emerges from a sign when the sign is used by people when communicating.

According to Peirce in Hoed (1992) a sign is something that represents something. That something can be an experience, a thought, an idea or a feeling. If something, for example $\mathrm{A}$ is black smoke billowing in the distance, then it can represent B, i.e. a fire (experience). Such a mark can be called an index; that is, between A and B there is a contiguity. A photo or picture is a sign called an icon. Photo represents a certain fact on the basis of similarity or similarity. A sign can also be a symbol, if the relationship between the sign and what it represents is based on a convention, for example, a red light that represents a 'prohibition' (idea) based on an existing agreement in society. Pigeon is believed to be a sign or symbol of peace; the pigeon cannot just be substituted by another bird or animal, and so on.

According to Pierce, a sign (representament) is something that can represent something else within certain limits (Eco, 1979: 15). Sign will always refer to something else, which Pierce calls an object (denotatum). A new sign can function if it is interpreted in the mind of the recipient of the sign through the interpretant. So the interpretant is the understanding of the meaning that appears in the recipient of the sign. The relationship between the three elements put forward by Pierce is known as the semiotic triangle. Furthermore, it is said that signs in relation to their references can be divided into signs known as icons, indexes and symbols.

Icons, indexes, symbols are a set of relationships between the base (form), object (referent), and concept (interpretant or reference). Form usually gives rise to perception and after being connected with an object will give rise to interpretants. This process is a cognitive process and occurs in understanding advertising messages. The series of understanding will continue to develop along with the series of semiosis that never ends. Furthermore, there is a series of semiosis levels. The interpretation is that 
there is a series of semiosis of the first layer, which will be the basis for referring to the new object and from here there is a series of semiosis of the second layer. So, what has the status of a mark in the first layer serves as a marker in the second layer, and so on.

Semiotics provides the possibility for us to think critically and understand the possibility of other meanings or interpretations of everything that happens in social and cultural life, including in ma'nene' rituals in the Baruppu community. So this research uses the semiotic theory developed by Charles Sander's Pierce to see the symbols and meanings contained in the ma'nene' ritual.

\subsection{Sign System}

Pierce sees the sign (representament) as an inseparable part of the object of reference, but is related to the object and its interpreter. So a sign we can form a triangle. The first is the sign itself, the second is the object which is the reference for the sign, and the third is the interpreter which is the introduction between the object and the sign.

The sign according to Peirce consists of a Symbol (a sign that emerges from a deal), an Icon (a sign that emerges from a physical representative) and an Index (a sign that arises from a cause-effect relationship). Meanwhile, the reference to this sign is called an object. The object or sign reference is the social context that is the reference of the sign or something that the sign refers to. Interpretant or sign user is the concept of thinking of people who use a sign and lower it to a certain meaning or meaning that is in someone's mind about the object that a sign refers to (Rahman, 2015).

Pierce's triadic model (representation + object + interpretant $=$ sign) shows the big role of the subject in the language transformation process. Signs in Pierce's view are always in a continuous process of change, which is called the process of unlimited semiosis, which is the process of creating an endless series of interpretants (Piliang, 2003: 266).

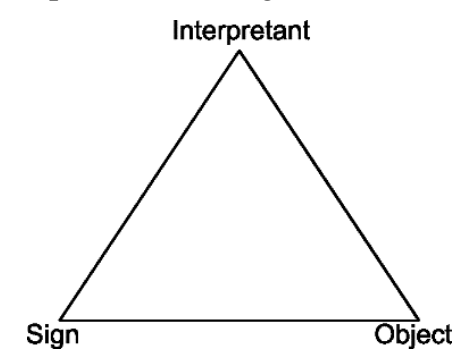

Figure 2.1 Pierce's triadic model

Pierce's triadic model shows three main elements forming signs, namely Representamen (something that represents something else), Object (something that is represented), and Interpretant (someone's interpretation of a sign) (Piliang, 2003: 267). According to Pierce, in studying the object he understands, a careful interpreter, everything will be seen from three things, namely: (1) The relationship of reasoning with the type of markers: (a) Qualisign: a marker related to quality, (b) Sinsign: a marker which is related to reality, and (c) Legisign: a marker related to the rules; (2) Relation of reality to its basic types: (a) Icon: Something that performs a function as a marker similar to the shape of the object (seen in a picture or painting), (b) Index: Something that performs the function as a marker indicating the sign, (c) Symbol: Something that performs a function as a marker which is conventionally used in society; (3) The relation of the mind to the type of marker (a) Rhema: The marker that is related to the object of the marker as possible to the interpreter, (b) Dicent or dicisign: The marker that displays information about the marker. (c) Argument: A marker whose final marker is not something but a rule.

\subsubsection{Symbol}

According to Spradley (1997: 125), symbolic systems can refer to language, art forms, the marriage procedures and so on. The symbol displays the relationship between the marker and the marker in its arbitrary nature. Interpreters are required to find the relationship between the signatures creatively and dynamically. Signs that turn into symbols will automatically be affixed with cultural, situational and conditional characteristics. Therefore, language is actually a great human achievement regarding arbitrary markers (Santosa, 1993: 11-12).

\subsubsection{Meaning}

Signs and meanings have the basic concept of all meaning models and which directly have similarities where each of them pays attention to the three elements that are always present in every study of meaning. The three elements are (1) sign, (2) sign reference, and (3) sign user.

In relation to the meaning process, especially in the meaning of a cultural structure, a knife or analysis tool is needed to dissect and find the meaning contained therein. In the ma'nene' ritual, which is a form of local wisdom in the culture of the Baruppu people, there are symbols. The Baruppu people use these symbols as part of a means of connecting humans and nature as well as supernatural beings on earth. These symbols have a philosophical meaning. Therefore, it is important for the author to interpret / translate these ancestral traditions, so that the younger generation as heirs as well as the continuation of local cultural wisdom can understand it and practice it in everyday life, in the form of teachings, values, and norms in life.

\section{Method}


The data collection method in this research is divided into two types, namely (1) library research which is sourced from literature, journals, previous research results, and the internet; and (2) field research that originates from semi-structured interviews with informants who are considered to be able to provide information about the object under study, and originate from recording and recording to transliterate and describe the data found.

\subsection{Data Analysis Method}

Data analysis was performed using Peirce's semiotic approach. The implementation technique is detailed as follows: 1) Classifying data relating to the use of symbolic forms and ma'nene' ritual background, 2) Translating data in the source language into the target language, 3) Analyzing the meaning of the symbols exist in ma'nene' ritual, 4) After the meaning of the symbol is systematically described, various cultural meanings can be related to the collectivity of the community supporting the ma'nene' ritual, and 5) Based on the relationship between cultural meaning and collectivity, the interpretation of local wisdom can be revealed.

\section{Results \& Discussion}

\subsection{Ma'nene' Ritual Steps}

The ma'nene' ritual is preceded by several activities related to the ritual preparation. After that initial series, then the ma'nene' ritual is carried out based on stages based on Aluk. This provision becomes the basis for the implementation of the ma'nene' ritual and each process in that provision has its own meaning and function. The following section will discuss the stages in the ma'nene' ritual.

\subsubsection{Preparation}

\section{a. Ma'kombongan ada'}

The first step in the preparation of the ma'nene' ritual is ma'kangga ada' which comes from the basic word kombongan which means gathering, conferring or deliberating to discuss and make decisions about family readiness, capacity, planned time, and preparation of the animals that will be sacrificed in the performance of the ma'nene' ritual. If the meeting has resulted in a kasiturusan (agreement) from all parties, then the ritual time can be determined, which is absolutely conducted after the harvest period.

\section{b. Kapenomban Pa 'paranduk}

Kapenomban pa'paranduk is a series of preparations before the implementation of ma'nene' rituals led by religious leaders or pastors by the church. This service begins the whole series of ma'nene' rituals which will be carried out for the next few days, aiming to ask permission and ask God for help so that all the sequences in the Ma'nene' ritual run smoothly.

The manta'da process was carried out according to the Protestant church order in Toraja. Manta'da itself is interpreted as the process of 'cleansing', or what Van (1987) calls the purification stage, which is the preparatory stage in which the families of tongkonan come together to present a pig intended to God, through the church as an attempt at "cleansing" which is meant as a confession of $\sin$.

The goal is to give thanks for the life of the Sustainer and ask for blessings as the tongkonan is a place for human life to make sacrifices. This stage is also intended to ask for a smooth process in the sacrifice that will be carried out in the next stage of the ritual.

\section{d. Ma'pakande ada'}

Ma'pakande ada' is the process of slaughtering the pork as the sacrifice on the first day. The distribution of pork is not only addressed to traditional leaders, but also to the church, which has now played many roles in replacing Aluk Todolo in traditional rituals. (interview with Reza Sarambu, 89 years old, 12-102017 11:00).

Ma'pakande ada 'is interpreted as a form of gratitude from the family group that will hold the Ma'nene' ritual to traditional leaders and churches and is a way for families to gain legitimacy from the community for social status and increase the role of their tongkonan in the customary order.

\section{e. Umpasun bombongan}

Umpasun bombongan is a procession of 'taking out the gong'. So that when the bombongan is sounded, relatives and local people will know and come to take part in the ritual. This gong is echoed along the way to the cemetery, as a sign of gratitude and joy for the family who will begin the implementation of the ma'nene' ritual.

\subsubsection{Implementation}

\section{a. Ma'bungka liang}

On the first day, the implementation of the ma'nene' ritual begins with the ma'bungka stage' opening the door 'of the liang. On the first day the door to the tomb was only opened without removing the body. First, they cleaned the area around the tomb and made huts around the cemetery area in preparation for entering the Ma'kassa'i stage on the second day. 


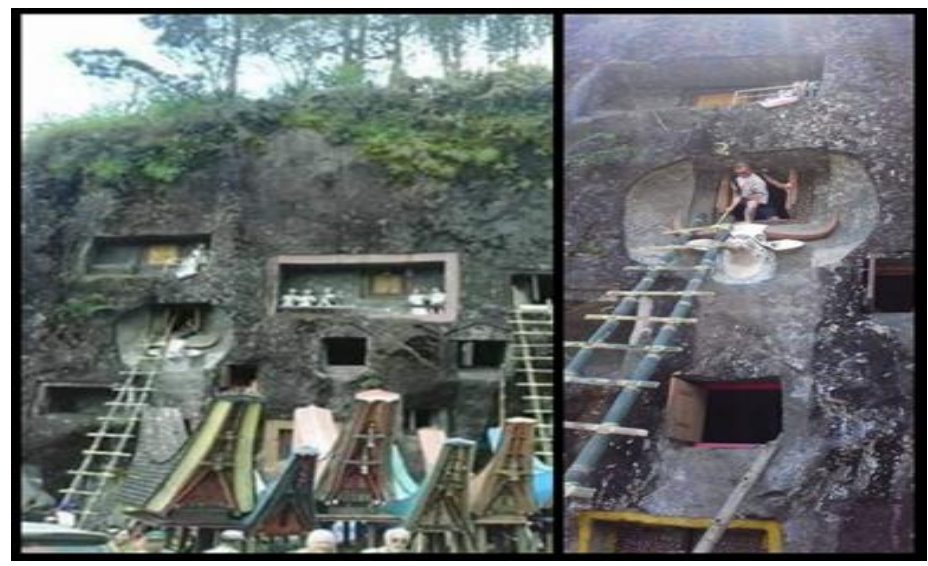

Picture 4.1 The implementation of the Ma'nene' ritual begins with the Ma'bungka' stage of 'opening the door' of the liang 'grave of stones'.

\section{b. Ma'kassa' $i$}

On the second day of implementation, the ma'kassa'i stage, which begins with the massonda bayu tau-tau (changing the clothes of the statue which is rotten or damaged). After that, lowering the corpses one by one from the burrow, starting with the oldest corpse, then placed and dried around the burial area. After drying the corpses in the huts, it is prepared for cleaning and renewing the cloth.
Ma'kassa' $i$ is carried out for the next three days according to the agreement of the family rumps, including replacing rotten or damaged crates and if there are rnayat that will be moved to a new liang or patane made by the family. On the last night of ma'kassa' $i$ on the fourth day, before the next day the corpses were put in, they also stayed in the huts so that they could accompany the ancestors, this was also a sign of their love and respect for the ancestors.

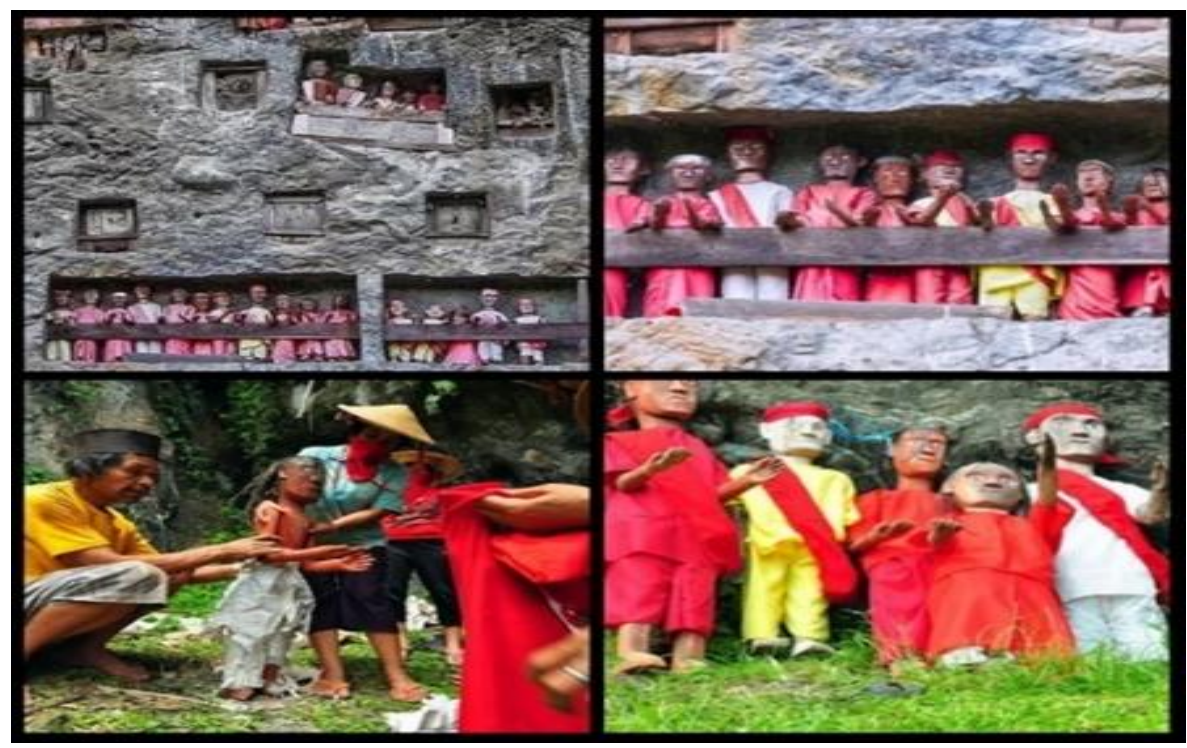

Picture 4.2 Massonda bayu tau-tau 'change the clothes of the statue' that has been weathered and damaged.

\section{c. Massomba tedong}

Massomba tedong is a ritual marked by a sacrifice in the form of a black buffalo. Massomba tedong is defined as an all-night prayer activity in which it contains praise for the buffalo to be offered." (interview with Novrianto, 30 years old, 29-09-2017 13:00)

The concept of worshiping deata or ancestral spirits in massomba tedong, is completely replaced by worship of God according to Christianity. However, this modification to the massomba tedong still does not change its role and function in the ma'nene' ritual. In the massomba tedong, the speech is delivered by the priest in the ma'nene' ritual which is preceded by thanking God as the creator of everything that exists. (interview with Aprilianto, 27 years old, 28-09-2017 16:00). 


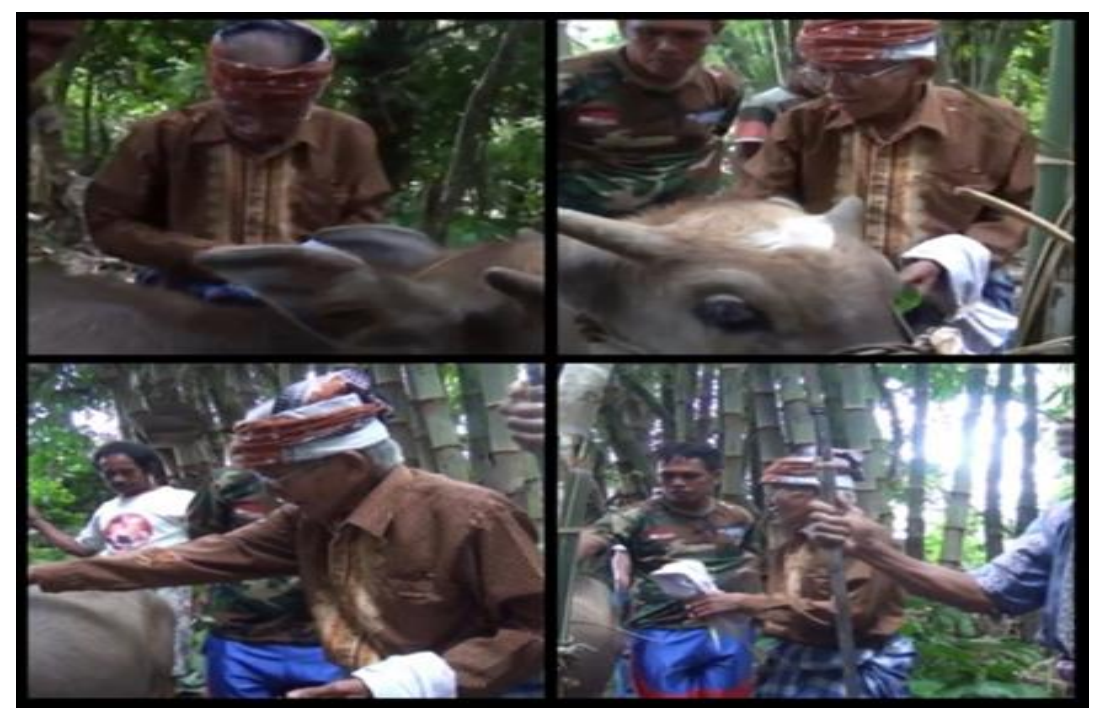

Picture 4.3 A black buffalo that will be a sacrifice in the ritual is first prayed by to-minaa

\section{d. Manglokko' tedong sola bai}

The next stage on the fifth day is the process of slaughtering a sacrifice in a grave area called manglokko' by the Baruppu community. Before the buffalo is sacrificed by using a spear, it is initially prayed for in a narrative expression which tells the glory of Puang Matua, all his creations and human life, and also condemns the bad deeds of humans required by the statement through the sacrifice.

\section{e. Ma'pakande nene'}

Ma'pakanbde nene 'is a ritual of delivering offerings to the ancestors. This is the essence of the ma'nene' ritual which contains the recitation of prayers, the presentation of the sacrifice, the finalization, and the inauguration of tomembali puang who is in charge of supervising and blessing his human descendants. (interview with Tato 'Dena', 82 years old, 27-09-2017 16:00). In this stage, the messenger prepared banana leaves as a serving place. After everything is ready, the next step is that the offerings are placed in front of the hole.

The messenger who eats the offering symbolizes the ancestral spirits who come to eat the offerings that have been provided in the messenger's body. Then, all those who are present at that place can eat together too so that the blessings of the ancestors can be abundant so they can be kept away from the evil disturbances and disasters that can befall the family.

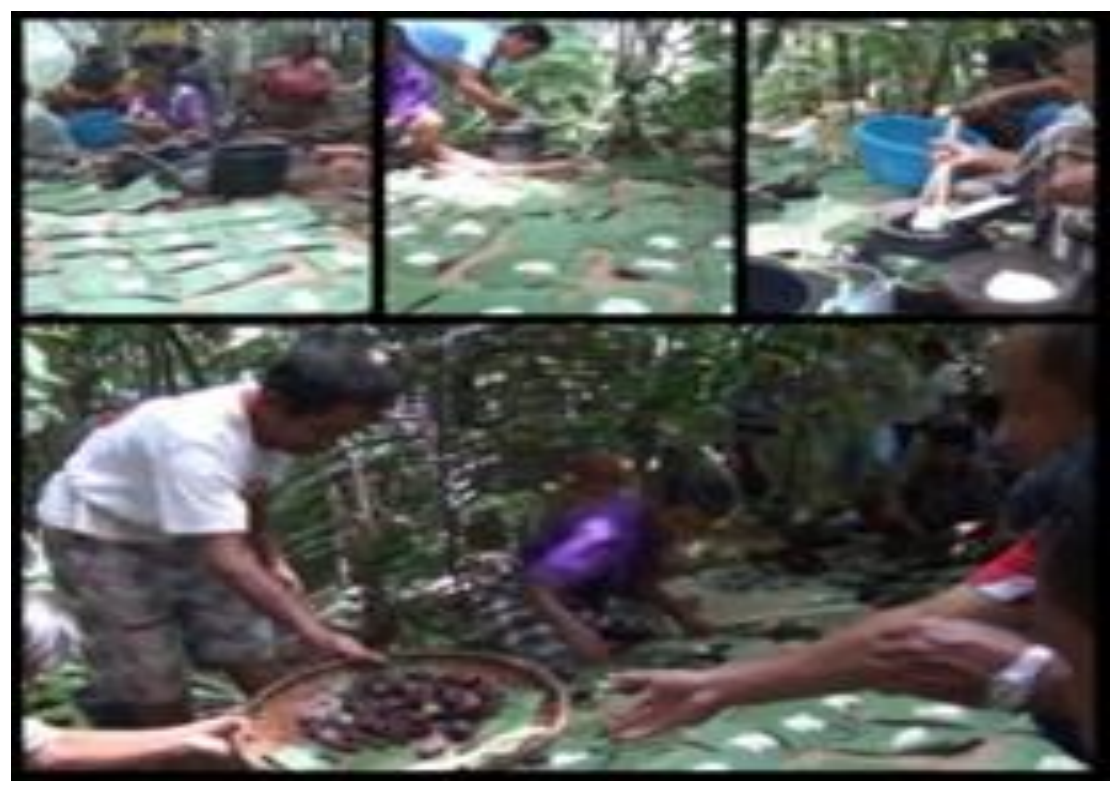

Picture 4.4 The community prepares dishes to be offered in rituals 


\section{f. Mantutu'}

then the messenger closes the door to the burrow as a

The next stage is mantutu 'closing the door'. In this step, the corpses are put back into the burrow,

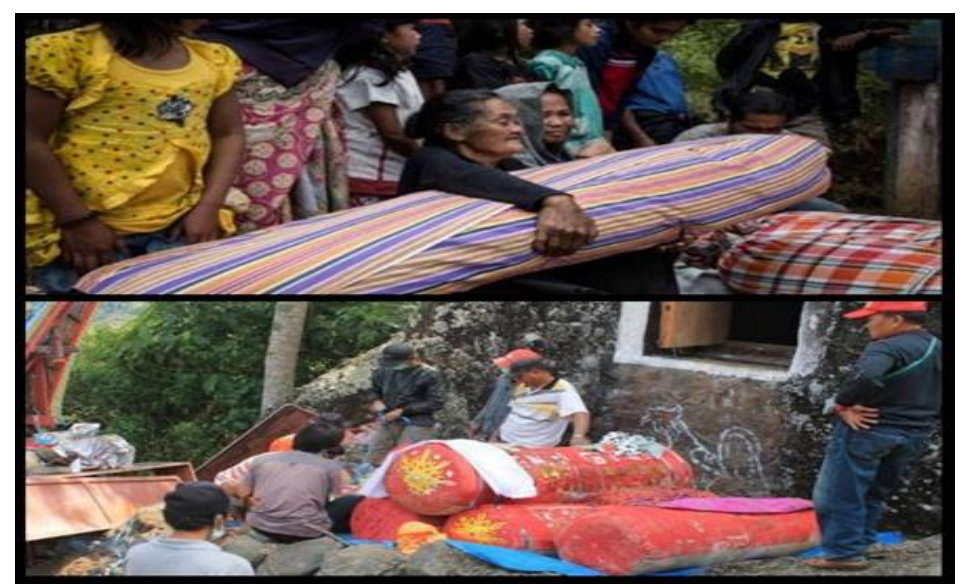

Picture 4.5 The process of entering the bodies one by one, starting with the oldest corpse.

\section{g. Kapenomban Pa'paupu'}

The series of the ma'nene' procession ends with the gathering of family members in the rante to worship together. This is where the family and all Вагирри people who have carried out the ritual gather and offer prayers of gratitude for the completion of the entire ma'nene' ritual procession which has gone well and smooth.

The Kapenomban Pa'paupu' (closing service), is followed by Sisemba' (playing feet) as a form of gratitude and happiness over abundant food and a symbol of unity which is capable of strengthening togetherness and brotherhood of the Toraja people.

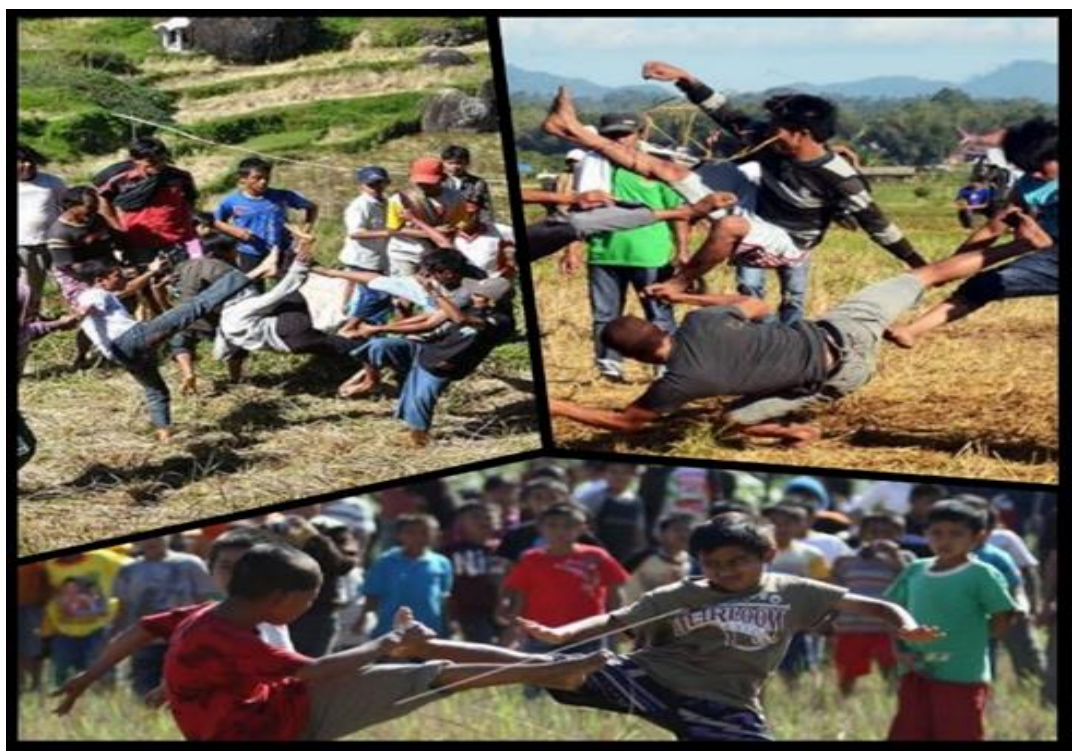

Picture 4.6 Sisemba (playing feet).

\subsection{Symbolic Interpretation in the Ma'nene' Ritual}

After analyzing the stages in the implementation of the ma'nene' ritual in the Baruppu community, the next section will discuss the interpretation of the symbols in the form of objects used in the ritual.

\subsubsection{Tau-tau}

The tau-tau symbol is a type of statue made of jackfruit wood. The word tau-tau in Toraja means 'human' or 'statue'. In the past, tau-tau were produced only for the rich, to symbolize the social status and wealth. In the teaching of Aluk Todolo, tautau is the new body of the spirit of the god-to-be. The statue was placed on the left side of the corpse overnight to catch the spirit of the dead. The goal is to 
create future ancestors. These deities are highly trusted by the followers of Alukta.

According to Aluk Todolo's teachings, after a person dies, his spirit lives in a supernatural realm and to commemorate the grave of ancestral spirits, a symbol is made that can be likened to a picture or photograph. Among the aristocrats, people feel closer to their ancestors with tau-tau media. In addition to the Torajan belief in Aluk Todolo, all objects on the face of the earth have spirits. They believe that their ancestral spirits can enter the tau-tau, so their descendants can always connect to their ancestors.

The existence of social layers or groups contained in the Toraja tribe community is very influential in the procurement of tau-tau. The death of the lowest strata of society tanaa karurung (the servant class/lowest in the Toraja society) is not ritualized using tau-tau. Not all ancestors can be worshiped or worshiped. Ancestors who can be raised as ancestors who can be worshiped and worshiped are those forefathers who have been urrinding tondok 'to defend the people', they are considered to have a special power of influence, based on their glory on earth, based on their wealth and position in society.

Thus, the meaning of the tau-tau symbol is intended to show the identity of the family, a tau-tau statue symbol is made for a family that is rich or has power, influence and position in Toraja society.

\subsubsection{Bombongan}

In the ma'nene' ritual there is also a 'gong' as a symbol and paraphernalia in the ritual, however, not everyone who perform the ma'nene' ritual uses the bombongan 'gong'. The gong that is played in this ritual is only performed by families who have performed the Rambu solo ritual at the Rapasan level, which is the highest ritual in Rambu solo' with a certain number of sacrificial animals. Umpasun bombongan in this ma'nene' ritual also indicates that one day the family will carry out the highest Rambu tuka ritual, namely $m a^{\prime} b u a^{\prime}$ which is an expression of gratitude for livestock, plants and human life. (interview with Novrianto, 30 years old, 28-09-2017 11:00).

Thus the bombongan 'gong' is interpreted as a symbol of connecting between rambu solo' and rambu tuka' because it is mandatory for Toraja people in general to carry out the Rambu tuka ritual (thanksgiving offering) as a request so that everything is better, by perfecting ritual activities to achieve the highest stage is kasa'tian (a prerequisite for being able to return to the sky as a god called to membali puang). The word sa'ti means 'to abide, to abide'. This means that he has reached the highest level of humanity, namely kindness, sincerity, and generosity that comes from him, towards others, ancestors, spirits and the surrounding environment.

\subsubsection{Pangngan}

The Pangngan 'betel' symbol in the ma'nene' ritual in the Baruppu community is mandatory. Besides, Pangngan itself is inseparable from the life of the Toraja people, both in Rambu Solo' and Rambu Tuka'. Pangngan 'betel' consists of kalosi 'areca nut', cake 'fruit betel', sambako 'tobacco', and kapu 'lime'. At the kapuran pangngan stage, it is interpreted as a way to only serve betel nut while praying something that will later make sacrifices. This means that it is a sign that in the near future, the family will make a sacrifice. In the ma'nene' ritual, the ingredients for the offering can be interpreted in various ways, such as pangngan 'sirih' is meant as a form of affection for the ancestors who also ate pangngan during their life. Thus, kapuran pangngan is interpreted as a sincere respect by bringing offerings and performing ritual stages according to the rules (Interview with Beatrix Bulo ', 80 years old, 27-09-2017, 13:00).

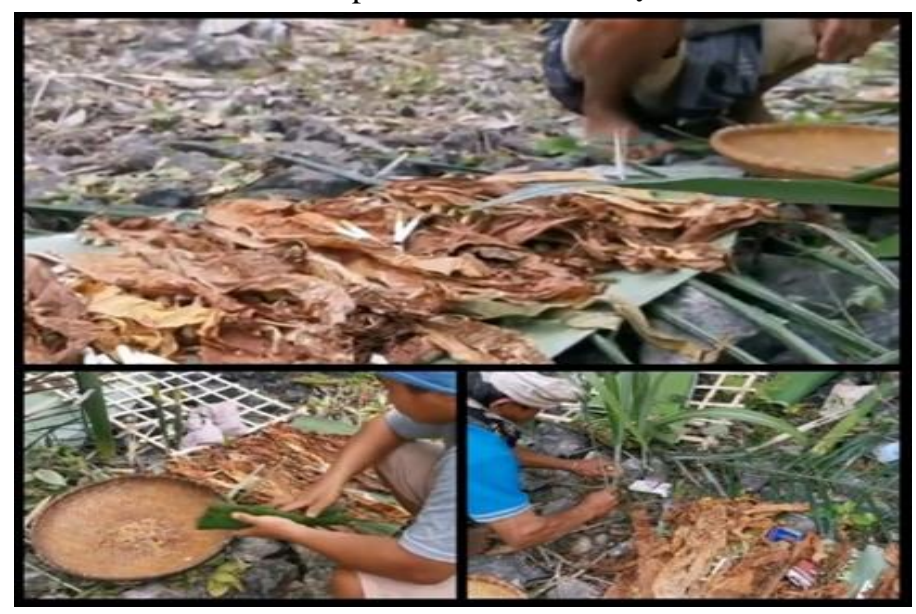

Picture 4.7 Pangngan 'sirih' used in ritual

\subsubsection{Ba'ru Cloth}


The symbol of cloth is one of the most important equipment in the execution of the ma'nene' ritual, because later the corpse that has been removed from the burrow will be changed or the clothes are renewed. The cloth ba'ru which means 'the new cloth' is the cloth used in rituals, and symbolizes a renewed bond. For the Baruppu people, death separates physically, but mentally it does not a separate the dead and the love of their children, grandchildren, and their families through the ma'nene' ritual.

\subsubsection{Tedong Sola Bai}

The most important animals in the ma'nene' ritual are chicken, dog, pig and buffalo. The buffalo that is the target of the chosen 'sacrifice' according to Aluk belief is a direct agreement made among Puang Matua as the creator, the ancestors of humans, and the ancestors of the buffalo as creations. Therefore, buffaloes become sacred animals compared to other animals that are offered in ma'nene' rituals. Buffaloes and pigs are believed to have ancestors who were related to humans. Unlike the selected buffaloes during the death ritual, they are big, strip-skinned, and completed with long horns. The buffalo chosen for sacrifice in the ma'nene' ritual is a black buffalo with short horns, which is about half the size of the adult one's arm. (interview with Tato Dena ', 82 years old, 28-09-2017 17:00).

As the buffalo of choice, this black buffalo must have eight marks resembling a white dot around its body, so that this black buffalo is considered worthy of being sacrificed in the tedong massomba. Therefore, buffaloes are well cared for. If these animals are to be sacrificed, it is necessary to have the Massomba Tedong ritual first, which is told in the creation myth in which it is said that they were slaughtered according to the mutual agreement of their previous ancestors.

After one by one the material elements in the ritual are grateful, the priest continues his narrative and begins to talk about the origins of the buffalo ancestors. The pastor started his story as if he were in dialogue with the buffalo to be made an offering, conveying the past agreement about his ancestors which Puang Matua asked to become a human sacrifice. Also with adulation to take his heart, every part of his sacrificed body can be interpreted as bringing prosperity to the whole family.

The purpose of all actions in the ma'nene' ritual is that these animals can be used for offerings to bring sustenance, but humans must not be greedy for excessive slaughter, and follow the rules set out in the Aluk, and are interpreted as an expression of gratitude for farm animals, plants and human life.

The purpose of all actions in the ma'nene' ritual is that these animals can be used for offerings in order to bring sustenance, but humans must not be greedy for excessive slaughter, and follow the rules set out in the Aluk, and are interpreted as an expression of gratitude for farm animals, plants and human life.

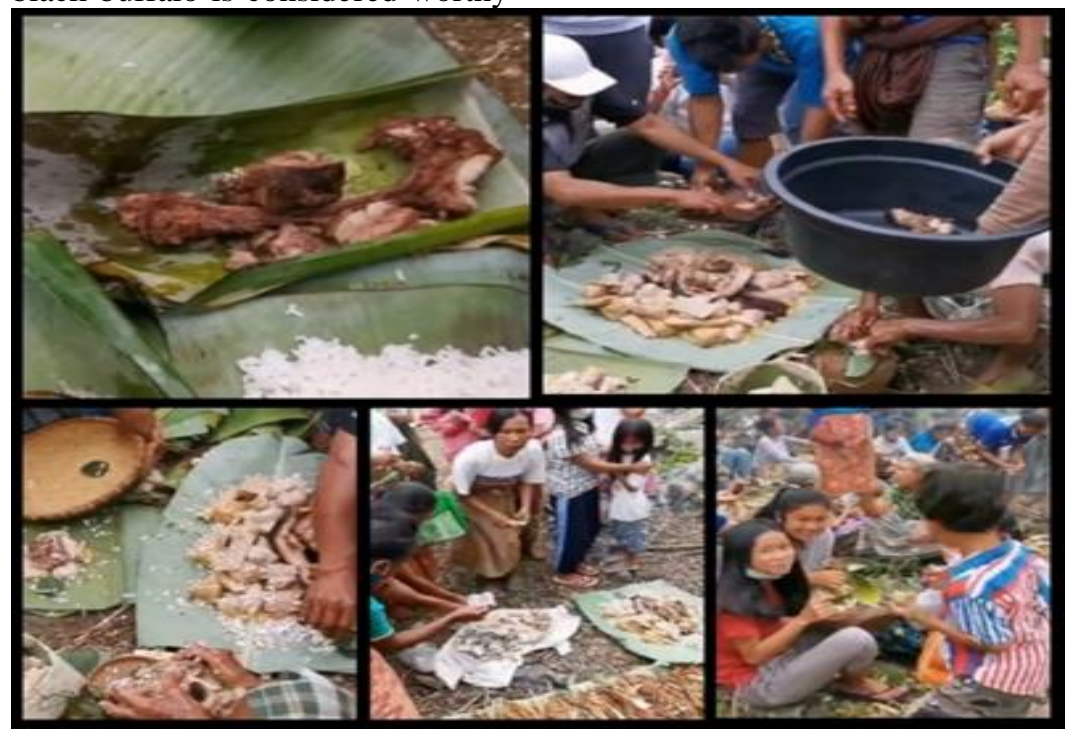

Picture 4.8 Family and community groups take ritual offerings and distribute the to relatives who come as a sign of thanksgiving

\subsubsection{Bo'bo 'SolaDuku}

Bo 'bo' which means' rice' is interpreted as a symbol of prosperity and a symbol of fertility. Duku' which means 'flesh' symbolizes the integrity of the life of the family family in the sense that the children and grandchildren are always in a healthy state and are blessed. When humans still have heart, liver, lungs wrapped in ribs, and still function normally, the human body is still intact as a human being. In the last 
part of the prayer to the buffalo in the massomba tedong procession, it is also stated that every part of its body is interpreted as a valuable jewelery from the family (Interview with Beatrix Bulo', 82 years, 28-092017, 17:00).

\subsubsection{Punti Leaves}

The banana leaves used in ma'pesung in the ma'nene' ritual come from two kinds of banana leaves, namely langkiran banana leaves and manurung banana leaves. Langkiran banana leaves are carved on the top and it was created by the gods. That is why this banana leaf is associated with the gods, while the manurung banana leaf, which is not carved, is associated with the ancestors. If you do pesung in the barn, the leaves used are punti manurung leaves. This is consistent with the direction of the lumbung which leads to pollo'nawai 'ancestral direction', namely the direction of the ancestors. If you memala', the banana leaf that is cut is the one facing the ulunna wai and the kabu'tuan allo' (the direction of the rising sun). On the other hand, if you do the ma'tomate ritual, the leaves taken are facing the pollo'nawai and the kalambunan allo' (towards the sun goes down). If you do pesung and to minaa facing the rising sun, the tip of the left leaf will face the direction of ulunna wai, namely deata ponno padang (a symbol of life) and the bottom part of garonto' is facing pollo'na wai. The tip of the right leaf will face toward pollo'na wai or ancestor and garonto'na will face towards ulunna wai. (interview with Aprilianto, 27 years old, 02-10-2017 16:00).

Banana leaves are multifunctional plants so that the parts of the tree can be used in human life. Likewise, for the Toraja people, banana leaves can be used as a substitute for plates for eating. Banana leaves continue to regenerate. When some leaves get old, the next fresh leaves are ready to replace them. Thus, the banana leaf is interpreted as a gift of blessings from the Creator.

\subsubsection{Tallang}

In the ma'nene' ritual, there is also a tallang 'bamboo' symbol which is carved and arranged in three ways that are not parallel as a sign that carries out from all levels of society regardless of social status. Bamboos are arranged in upper, middle, and bottom layers that represent differing social positions ranging from the high until the low ones. Most importantly, the three bamboos contain water to drink: tuak (a traditional drink derived from the juice of the mother tree or sugar palm) and pig's blood mixed with buffalo blood. The red color of the sacrificial blood represents human life, and the white color of the palm wine and the bone represents purity. In addition, bamboo is a type of plant that grows in clumps and is an integral part of the life of the Toraja people. (interview with Hardi Rupang, 80 years old, 10-11-2017 22:00).

For the people of Toraja, bamboo can be used as a material for making huts, houses, walls, even roofs, and so on. In addition, it also symbolizes unity in Toraja society as swhown in the Toraja literary expressions which says 'ma'rapu tallang' which means 'like clump of bamboo'and ma'tallang tang kalesoan' which means 'bamboo without segments' which symbolizes sincerity and honesty. Other ingredients used as ma'nene' ritual offerings are interpreted as sources of life. In this connection, water and tuak are also used as offerings because it is believed that a person who dies also feels thirsty as when he was alive.

\subsection{Interpretation of Local Wisdom in Rituals}

In building Toraja society, it is necessary to pay attention to cultural aspects. This is because the noble values that appear in the symbolic order contain meanings that can support social integration, such as religious values, social values, and values related to the Toraja people as creators of the work. Various cultures and local wisdom should be preserved and maintained because they are rich in values and moral teachings.

\subsubsection{Religious Values}

Toraja people are measured by their behavior (penggauran), participation in rituals (tongkon dan ma'barra 'sang raku'), and the activity of performing the ritual itself (mekaluk). Every behavior, and steps of life (tengka ke'de'na) are guarded, regulated, and monitored by the gods. So, every behavior in ma'nene' ritual is a religious act.

Ritual acts and instruments show human respect for things beyond human ability. Offerings are used as a form of harmonious interaction between humans and all elements of the universe and as respect and love for ancestors. This is described in the term 'Tallu Lolona' which represents a harmonious relationship centered on three relationships, namely: (1) humans and Puang Matua and ancestors, religion, pemali, truth and Ampu Padang, (2) humans and humans, (3) humans with nature, namely animals and plants. Maintaining this very diverse relationship with nature is very important as stated by Rahman et al., (2019) that the biodiversity plays a vital role in supporting the entire ecosystem including air quality, climate, carbon dioxide uptake, water purification, pollination, and erosion prevention. One proof of the relationship between humans, animals and plants is the ma'nene, ritual which represents a relationship between human and the Almighty.

\subsubsection{Brotherhood}


Torajan cultural knowledge and belief systems place human together with other living things to live in harmony. Humans are part of nature and there is a relationship between the two. As fellow creatures of God, nature is obliged to support humans and humans are obliged to preserve nature. This brotherhood appears in a harmonious relationship with animals and nature. Local wisdom constructed in the oral tradition through rituals in the Toraja people can be utilized for the management of their natural environment. The main point is to build a relationship between humans and nature as a subject-subject relationship by applying 'sibling relations'. Meanwhile, the nonsibling (subject-object) relationship will only bring out greed.

As for sibling relations (subjects) which are based on religious teachings, hereditary truths, and mediation through rituals, it is believed that they can bring fertility and life. As social beings, humans cannot fulfill their own needs alone so they need help from others. The togetherness contained in the ma'nene' ritual, is in the form of mutual cooperation which can be in the form of labor, goods and other assistance.

\subsubsection{Unity}

In various ritual ceremonies in Toraja society, it can be seen that the social relation among humans is regulated in ritual and daily behavior. The Toraja people are always careful in their daily behavior and ritual behavior. This harmonious order refers to honesty, clean life, pluralism, discipline, hard work, democracy, education, national spirit, peace-loving, communicative, environmental care, social responsibility, mutual respect, and mutual help. The main theme of this culture moves on the value of unity in relation to the background of brotherhood as seen in the norms of kasiuluran 'brotherhood', kasipulungan 'gathered together', kasiangkaran 'mutually supporting', kasiturusan 'mufakat', kasialamasean ' love each other ', kasi budget' mutual respect ', case of' mutual respect.

\section{Conclusion}

Based on the discussion of this research, the following conclusions are formulated as follows; 1) Ma'nene' is a toraja custom which is carried out systematically in which the stages of implementation are: ma'kongan ada', kapenomban pa'paranduk, manta'da, ma'pakande ada ', and umpasun bombongan. The series of implementation of the ma'nene' ritual has the stages of ma'bungka liang, ma'kassa'i, massomba tedong, manglokko' tedong sola bai, ma'pakande nene ', mantutu', and kapenomban pa'paupu ', which means that the ma'nene' cannot be done if it is not an agreed time like the ma'nene' ritual in the people of Baruppu, North Toraja Regency. Meanwhile, there is also a customary area which names lao lako tomatua (lao = to go; lako = to $=$ to; tomatua $=$ parent or ancestor). This ma'nene' ritual is carried out after the harvest / cutting of rice because it is believed that the good harvest is due to the blessing of tom Kembali puang who always pay attention to the life of his descendants. The understanding of Ma'nene' rituals in the Baruppu community is seen as a symbol and appreciation carried out by children, relatives to their loved ones and their concept of mind sees that there will be spirits who will bless them when performing the ma'nene' ritual; 2) The ma'nene' ritual cannot be separated from various symbols that contain religious values and even meaningful social values for the Toraja people, including: untundan mali', ungkassa' $i$ pa'kaboro', umpamarra' paumpuran, ungkadang lama', and umpaundi polean; 3) What should be adhered to by the Church, namely: untundan mali' (longing, appreciation, to parents and ancestors who have contributed to life), ungkassa'i kaboro' (socially disconnected, but in fact love never dies. is something to be remembered for), umpamarra' paumpuran (parents are the knot point of an offspring. By meeting together in ma'nene' moments, the kinship relationship is strengthened), ma'kadang tua' (parents are a blessing from God to be grateful, so be thankful to God), and umpaundi polean (should not be done anymore, offerings only to God). Give thanks to God for God's love through parents, predecessors, and who have taught about life. The greatest sacrifice is the offering of oneself to worship God.

\section{References}

Akhrani, L. A., \& Eka, G. (2019, March). Anxiety About Aging: Cultural Value Masyarakat Toraja. In 4th ASEAN Conference on Psychology, Counselling, and Humanities (ACPCH 2018). Atlantis Press.

Alam, F. A., \& Al-Muthmainnah, A. M. (2020). Exploring Local Wisdom in Buginese Ethnics: Language Politeness Phenomena of Tau Soppeng. REiLA: Journal of Research and Innovation in Language, 2(1). 14-18. https://doi.org/10.31849/reila.v2i1.3767

Dewi, I. N., Poedjiastoeti, S., \& Prahani, B. K. (2017). Elsii learning model based local wisdom to improve students' problem solving skills and scientific communication. International Journal of Education and Research, 5(1), 107-118.

Eco, U. (1979). A Theory of Semiotics. Indiana University Press.

Hamuddin, B., Syahdan, S., Rahman, F., Rianita, D., \& Derin, T. (2019). Do They Truly Intend to Harm Their Friends?: The Motives Beyond 
Cyberbullying among University Students. International Journal of Cyber Behavior, Psychology and Learning (IJCBPL), 9(4), 32-44.

Hasmawati, H., Yusri, Y., Dewi, A. M., \& Gesrianto, J. (2020). Classification of Lingual Forms on the Lexicon of Kuburan in the Toraja People. RETORIKA: Jurnal Bahasa, Sastra, dan Pengajarannya, 13(2). 368-375

Hoed, B. H. (1992). Kala dalam Novel: Fungsi dan Terjemahannya. Yogyakarta: Gadjah Mada University Press.

Kausar, D. R. K., \& Gunawan, M. P. (2018). Managing heritage tourism in Toraja: strengthening local values and improving tourists experiences. Journal of Heritage Tourism, 13(6), 550-561.

Kobong, et al. (1992). Aluk, Adat dan Kebudayaan Toraja dalam Perjumpaannya dengan Injil. Pusbang-Badan Pekerja Sinode Gereja Toraja.

Kendek, V. (2015). Ma’nene' (Upacara Membersihkan dan Mengganti Pakaian Jenazah Leluhur pada Masyarakat BARUPPU). [Skripsi, Universitas Hasanuddin] https://core.ac.uk/download/pdf/77625997.pdf

Koenjaraningrat. (1992). Beberapa Pokok Antropologi Sosial. Jakarta: Dian Rakyat.

Koenjaraningrat. (1996). Pengantar Antropologi I. Jakarta: Rieneke Cipta.

Kriyantono, R. (2007). Teknik Praktis Riset Komunikasi. Jakarta: Kencana.

Niswaty, R., Nur, A. C., \& Sesa, D. R. (2020, October). Village Fund Allocation Management in Kapala Pitu District, North Toraja Regency. In 3rd International Conference on Social Sciences (ICSS 2020)(pp. 783-788). Atlantis Press.

Panuntun, D. F., Tanduklangi, R., Adeng, M., \& Randalele, C. E. (2019). Model Ibadah Sekolah Minggu Kreatif-Interaktif Bagi Generasi Alfa Di Gereja Toraja. BIA': Jurnal Teologi dan Pendidikan Kristen Kontekstual, 2(2), 193-208.

Piliang, Y. A., \& Adlin, A. (2003). Hipersemiotika: tafsir cultural studies atas matinya makna. Jalasutra.

Piliang, Y. A. (1998). Sebuah dunia yang dilipat: realitas kebudayaan menjelang milenium ketiga dan matinya posmodernisme. Mizan Pustaka.

Potts, D. (2017). C. Coffin and J. Donohue: A Language as Social Semiotic-Based Approach to Teaching and Learning in Higher Education.
38(5)

$768-771$.

https://doi.org/10.1093/applin/amw054

Rahman, F. (2015). Iconic Force of Rhetorical Figures in Shakespeare's Drama. Retrieved on Oct 26, 2020 from https://studyres.com/doc/9460016/iconic-forceof-rhetorical-figures-in-shakespeare-s-drama

Rahman, F., Akhmar, A. M., \& Amir, M. (2019, May). The Practice of Local Wisdom of Kajang People to Save Forests and Biodiversity: A CulturalBased Analysis. Proceeding In IOP Conference Series: Earth and Environmental Science. 270(1) 012038. IOP Publishing.

Rappoport, D. (2014). Nyanyian Tana Yang Diperciki Tiga Darah: Seni Suara dan Ritus-Ritus Toraja (Sulawesi, Indonesia). Kepustakaan Populer Gramedia bekerjasama dengan Ecole Francaise d'Extreme-Orient Ford Foundation Forum Jakarta-Paris.

Rappoport, D. (2009). Nyanyian Tana Diperciki Tiga Darah: Seni Suara dan Ritus- Ritus Toraja di Pulau Sulawesi, diterjemahkan oleh Stanislaus Sandarupa Songs from the Thrice-Blooded Land: Ritual Music of the toraja (Sulawesi-Indonesia), Florilegium Toraja. Kepustakaan Populer Gramedia bekerjasama dengan Ecole Francaise d'Extreme-Orient Ford Foundation Forum Jakarta-Paris.

Satoto, B. H. (1986). Simbolisme dalam Budaya Jawa. Yogyakarta: Hanindita GrahaWidia.

Santoso, Puji. (1993). Ancangan Semiotik Dan Pengkajian Susastra. Bandung: Angkasa.

Surya, W., Rahman, F., \& Makka, M. (2017). Folktale from England to Toraja. Imperial Journal of Interdisciplinary Research (IJIR), 3, 2454-1362.

Spradley, J.P. (1997). Metode Etnografi. Terjemahan oleh Misbah Yulfa. Yogyakarta: Tiara Wacana.

Tanasy, N., Nasir, A. M., \& Yulianti, N. I. R. (2020). Mapping the Linguistic Politeness of Dusun Tangkuru Society: The Pattern of Politeness in Makassar. Elsya: Journal of English Language Studies, 2(3), 45-50.

Van B. J. (1987). Sejarah dan Pertumbuhan Teori Antropologi Budaya Hingga Dekade 1970, Jakarta: PT Gramedia. 